$$
\begin{aligned}
& \text { مقايسة اثر حشرهك شيميايى موونتو با حشرهك زيستى كيتوزان بر سيستم توليدمثلى مادةٔ موش } \\
& \text { نزاد Balb/C نواد }
\end{aligned}
$$

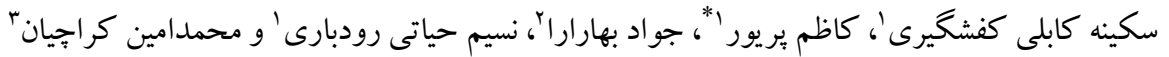

$$
\begin{aligned}
& \text { دريافت: } \\
& \text { اكروه زيستشناسى، دانشكدة علوم، دانشگاه آزاد اسلامى واحد علوم و تحقيقات، تهران، ايران }
\end{aligned}
$$

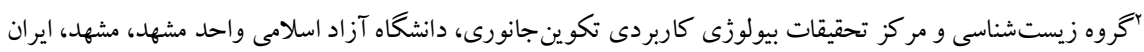

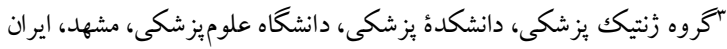

$$
\begin{aligned}
& \text { k.parivar@srbiau.ac.ir :مسئول مكاتبات }
\end{aligned}
$$

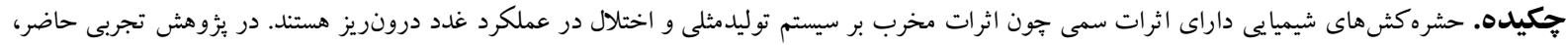

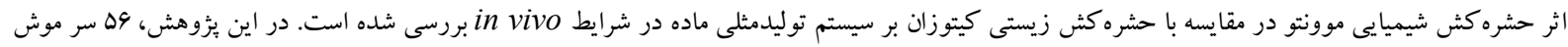

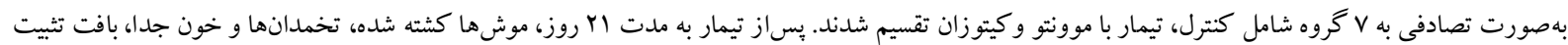

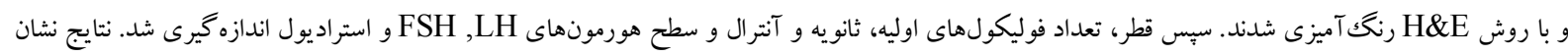

$$
\begin{aligned}
& \text { داد تيمار با كيتوزان بر تعداد و قطر فوليكولهاى اوليه، ثانويه و آنترال در گروههاى }
\end{aligned}
$$

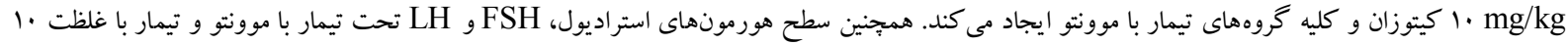

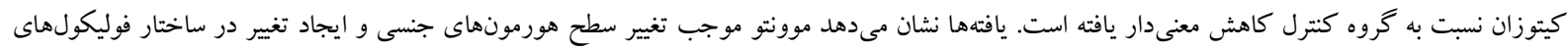

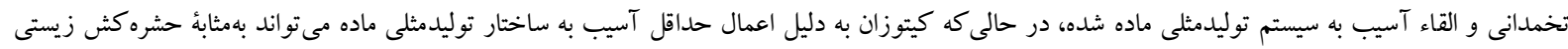

$$
\begin{aligned}
& \text { مورد استفاده باشد. } \\
& \text { وازههاى كليدى. تخمدان، فوليكول، هورمون جنسى بانس }
\end{aligned}
$$

\title{
Comparison the effect of movento, a chemical pesticide, with chitosan, a biologic pesticide, on female reproductive system in $\mathrm{Balb} / \mathrm{C}$ mice
}

Sakineh Kaboli Kafshgiri ${ }^{1}$, Kazem Parivar ${ }^{2}$, Javad Baharara ${ }^{3}$, Nasim Hayati Roodbari ${ }^{4} \&$ Mohammad Amin Kerachian ${ }^{5}$

Received 16.03.2016/Accepted 04.09.2016/ Published 18.03.2017

${ }^{1}$ Department of Biology, Science and Research Branch, Islamic Azad University, Tehran, Iran ${ }^{2}$ Research Center for Animal Development \& Applied Biology, Islamic Azad University of Mashhad, Tehran, Iran ${ }^{3}$ Department of Medical Genetics, Faculty of Medicine, Mashhad University of Medical Sciences, Mashhad, Iran *Correspondent author: k.parivar@srbiau.ac.ir

\begin{abstract}
Chemical pesticides possess toxic and destructive impacts on the reproductive system and disrupt endocrine function. In this experimental study, the effect of movento, as a chemical pesticide, was investigated in comparison with chitosan, a biological pesticide, on the female reproductive system in vivo. In this study, 56 mice were randomly dived into 7 groups including control and experimental groups treated with movento and chitosan. After a 21-day treatment, mice were killed and their ovaries and blood being collected. In addition, the samples were fixed and stained with $\mathrm{H} \&$ E method. The results exhibited that treatment with 2.5 and $5 \mathrm{mg} / \mathrm{kg}$ chitosan had no significant effect on the number and diameter of primary, secondary and antral follicles, while these items were significantly reduced in $10 \mathrm{mg} / \mathrm{kg} \mathrm{ch}-$ itosan group and all movento-treated groups as well. In addition, the level of sexual hormones, such as estradiol, FSH and LH, was decreased in $10 \mathrm{mg} / \mathrm{kg}$ chitosan group and all movento-treated groups in comparison with the control group. The findings showed that movento affected the sexual hormone levels, ovary and ovarian follicle structure and induced abnormality in female reproductive system, while chitosan, as a biological pesticide, should be used due to its minimum effects on female reproductive system.
\end{abstract}

Keywords. ovarian, follicle, sexual hormone 
دارد (Nauen et al., 2008). مطالعات روى اين تركيب ززارش كردهاند كه اين ماده باعث تغييرات در شاخصهاى بيوشيميايى

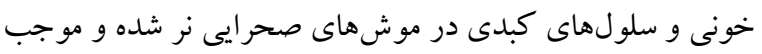
افزايش سطح ترى كليسير يد، كلسترول و آلبومين و ايجاد تغييرات

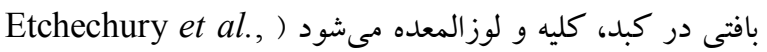

مطالعات نشان مىدهند موونتو باعث كاهش حركت، بيشروى

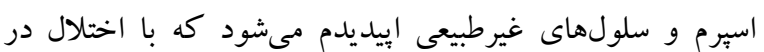

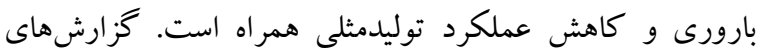
ديخر بيان گر اين است كه اين تركيب در طى رشد و نمو باعث كاهش مصرف غذا و وزن بدن، اختلالات رشد و اختلالات و ناهنجارىهاى اسكلتى، شكاف كام و نقص در ديو ارؤ بين دهليز و ميكروفتالمى مىشود ) \& Sverdrup et al., 2012; Fisher \& .(Weiss, 2008 در اين ميان حشرهكشهايى نيز وارد بازار شده اند كه زيستى بوده و حداقل آسيب را بر روى موجودات اعمال مى كنند.

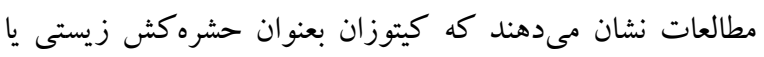
بيولوزيكك جديد براى كنترل آفات استفاده مى شود. كيتوزان يكك

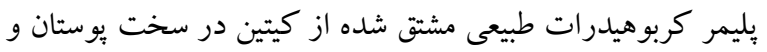

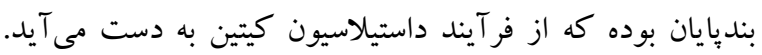

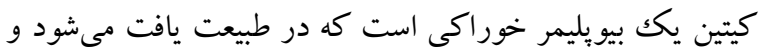

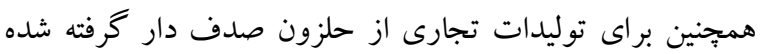
است. كيتوزان مقدار تنفس كياه را كاهش داده و بنابراين كيفيت ميوه را كنترل مى كند. همجنين اين تركيب داراى فعاليت ضد

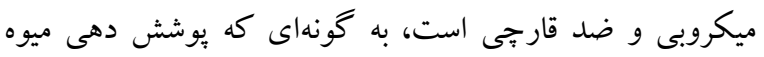

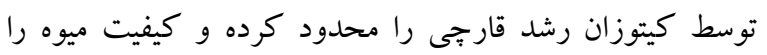

بهبود مىدهد (Yanti et al., 2009).

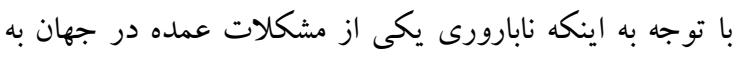

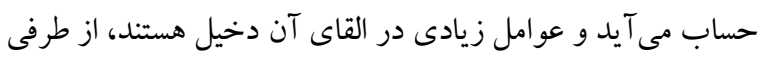

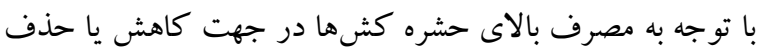

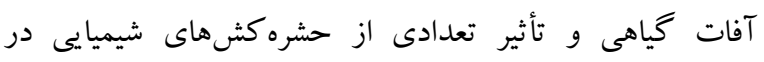

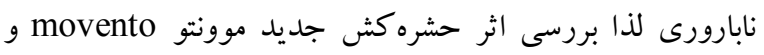

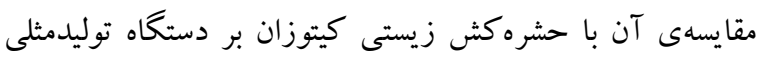

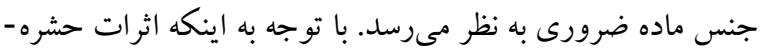

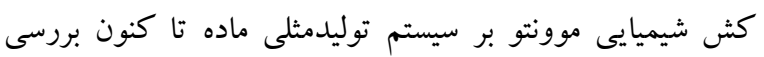

مقدمله

در سالهاى اخير آفت كشها مصرف گستردهاى در جهان بيدا كرده و دورى از آنها در حال حاضر غيرقابل اجتناب است ) (et al., 2011 بهطور كلى در كشاورزى كاربرد داشته و داراى اثرات سمى هستند (Ngoula et al., 2007). بسيارى از حشرهكشها داراى اثرات مخرب بر سيستم توليد مثل و همجِنين اختلال در عمل كرد غدد درونريز هستند، هم جنين مطالعات نشان دادهاند كه آنها باعث سقط جنين، تولد نوزاد نارس، كاهش بارورى در زنان و Mnif et al., ) مردان و بعضى از نقصهاى رشدونمو مى شوند 2011; Sangha et al., 2013 آسيب به سيستم تناسلى و تخريب مستقيم سلولى، سندرم نورولوزيكال، شكل گيرى تومورهاى بدخيم و سركوب فعاليت ايمنى و اثرات تراتوزنيك، سقط و كاهش بارورى در حيوانات ازمايشگاهى مىشوند (Meeker et al., 2006). نحوه عمل كرد آفت كشها متفاوت است كه مىتواند از نوع عصبى و يا اختلال گر در ترشح هورمون باشد (Mnif et al., 2011). ردههاى جديد حشره كشها اثرات مخربى روى سيستم توليدمثلى ماده دارند كه شامل تغيير در رفتار جنسى، بلوغ، بارورى، زمان بارورى و توليد شير است كه منجر به آسيب به سيستم توليدمثلى ماده مى شود (Ngoula et al., 2012). اختلالات تخمدانى مى تواند با عو املى از جمله سطح بالاى فعاليت فيزيكى، سن، استرس، سيگار و همجنين در معرض قرارگيرى حشره كشها ايجاد شود كه مى -

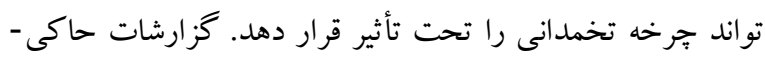
ازآن است كه آفت كشها باعث اختلال در عمل كرد هورمونى زنان و اثرات منفى بر بارورى مى شود و بويزه جرخه تخمدانى را

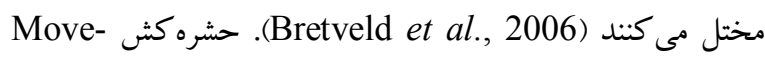
nto شيميايى از جرخه كتونولها (Ketenoles) هستند و از مشتقات اسيد تتراميك است كه با بيوسنتز جربى تداخل ايجاد نموده و منجر به مرگك آفات مىشود. مطالعات نشان مىدهند كه اين سم بdchechury ( بهور كلى باعث اختلال در سوختوساز مىشود et al., 2015 حشره كش در موشهاى نر در دوزهاى بالا باعث القاء تغييرات مورفولوزيكك روى اسبرمها شده و اثرات زيانبارى روى بارورى 


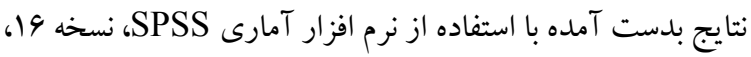

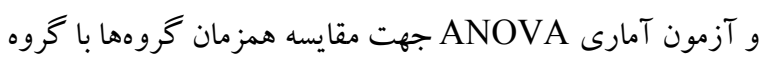

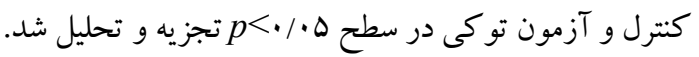

نتايج تعداد فوليكول هاى اوليه، ثانويه و آنترال تحليل آمارى اختلاف معنىدار بين ميانكين تعداد فوليكولهاى التهاى

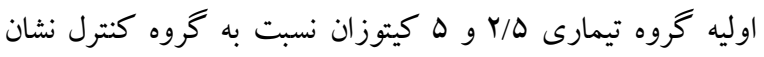

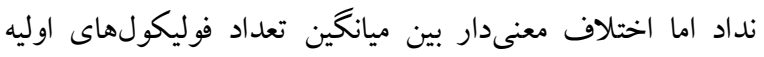

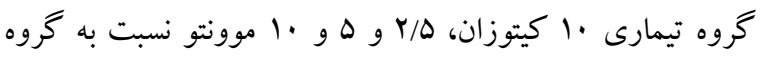
كنترل مشاهده شد (شكل A 1). تحليل آمارى اختلاف معنىدار

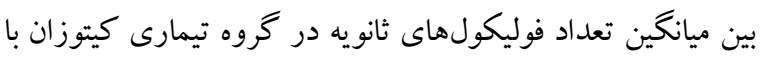

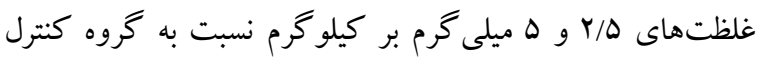

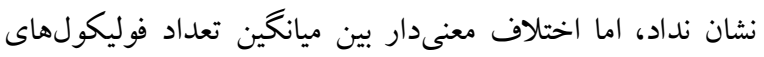

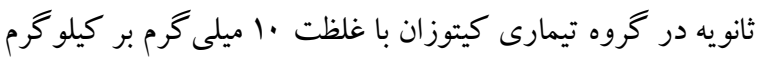

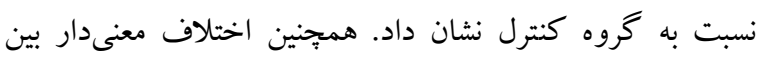

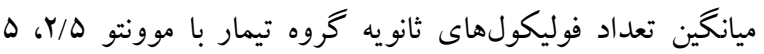

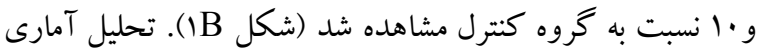

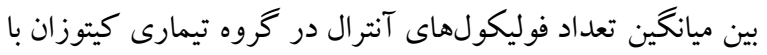

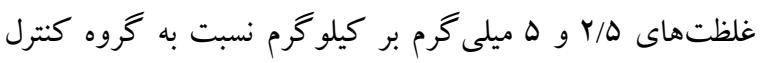

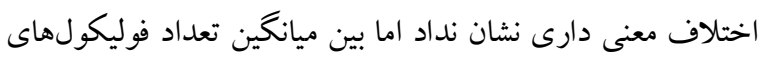

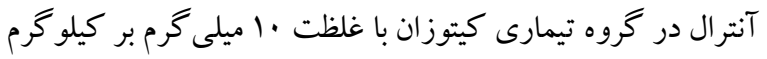
نسبت به گروه كنترل اختلاف معنىدار نشان داد، همجنين بين

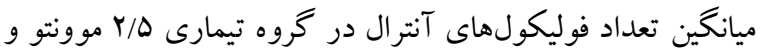

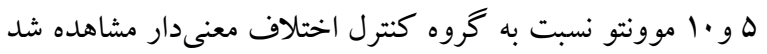

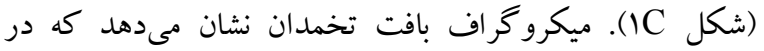

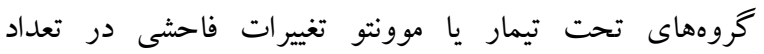

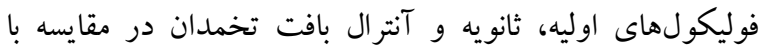

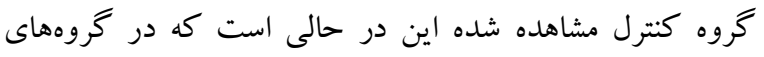

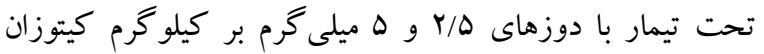

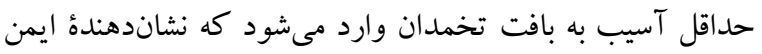

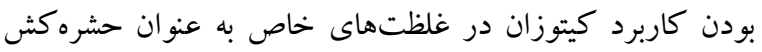

$$
\text { زيستى است (شكل r). }
$$

نشده است، در يُوهش تجربى حاضر اثر آفت كش شيميايى

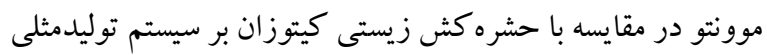

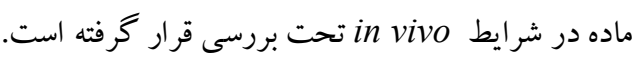

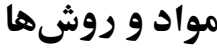

در اين مطالعه، وها سرموش سورى مادة 9 هفتهاى نزاد Balb/C

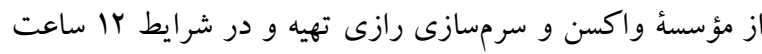

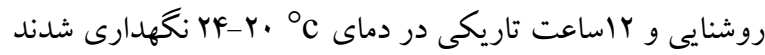

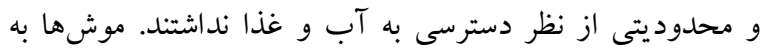
صورت تصادفى به ل گروه ^ نايى بهصورت زير تقسيم شدند.

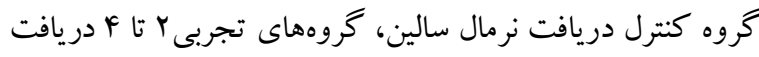

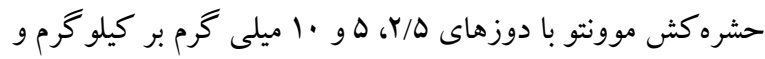

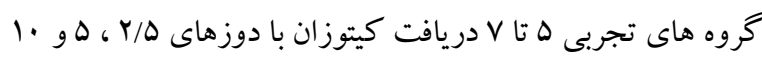

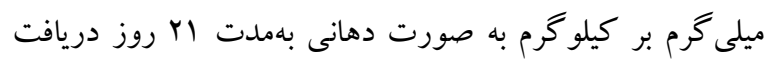

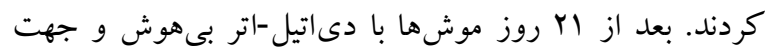
تعيين سطح سرمى هورمونهاى تخمدانى از قلب حيوان خون-

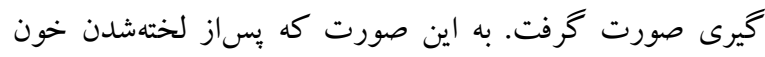

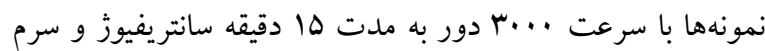

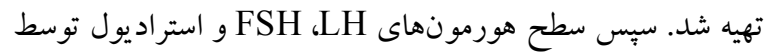
آزمون الايزا اندازه خيرى شد. وِساز خون گيرى از قلب، حيوانات تشريح، تخمدان و شاخه سمت راست رحم از هر موش خارج شد و بساز توزين، بافت-

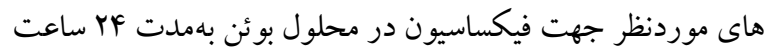

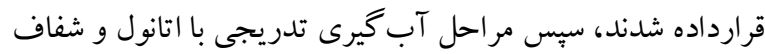

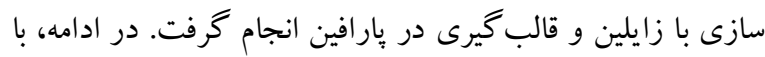
تهية برشهاى سريالى ه ميكرونى، با هماتو كسيلين و ائوزين

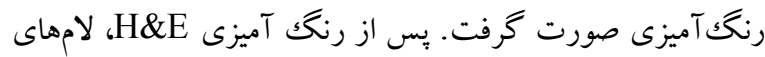

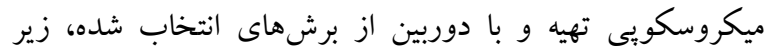
ميكروسكوبٍ نورى olympus عكس گرفته شد. در مقطع تخمدان تعداد و قطر فوليكولهاى اوليه، ثانويه و آنترال محاسبه

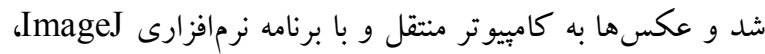

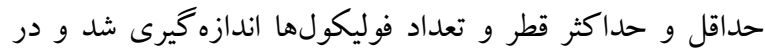
كروهها مقايسه شد. آناليز آمارى 


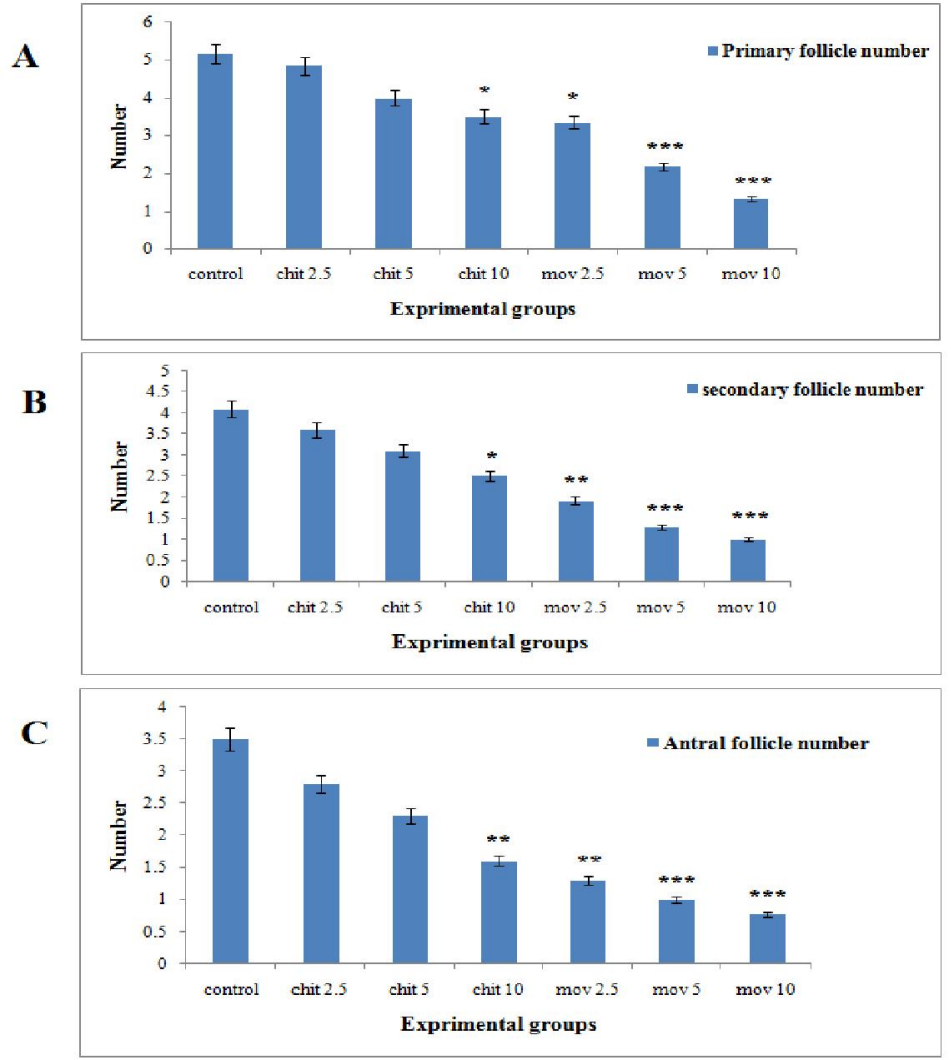

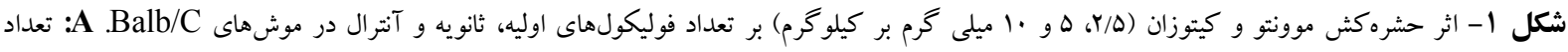

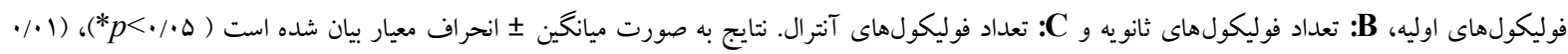

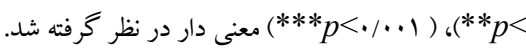

Fig. 1. The effect of movento and chitosan exposure $(2.5,5 \mathrm{and} 10 \mathrm{mg} / \mathrm{kg})$ on the number of primary, secondary and antral follicles in Balb/C mice. A: number of primary follicles. B: number of secondary follicles. C: number of antral follicles. The results are the means \pm SD. $p$ value of ${ }^{*} p<0.05,{ }^{* *} p<0.01$ and ${ }^{* * *} p<0.001$ were considered significant.

كروه تيمار با غلظت ه/ Y و ه و •ا موونتو نسبت به گروه كنترل

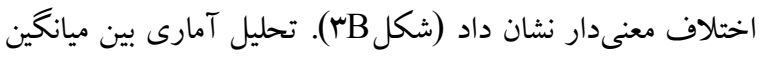

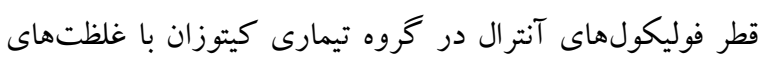

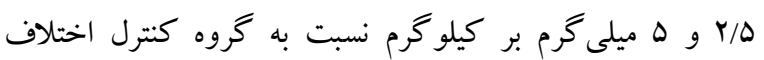

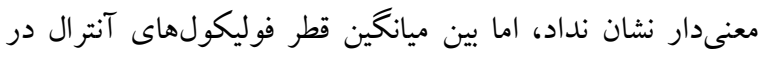

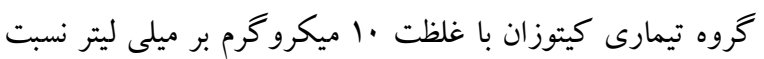
به گروه كنترل اختلاف معنى دار نشان داد. همجنين بين ميانگين

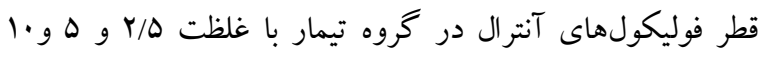

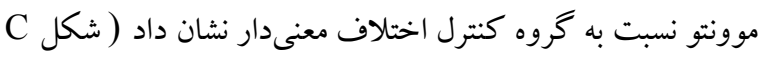

\section{اثر موونتو و كيتوزان بر سطح هورمونى}

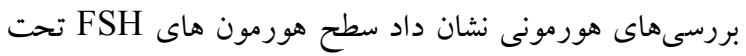

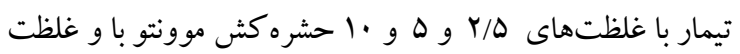

تحليل آمارى بين ميانگين قطر فوليكولهاى اوليه در گروه

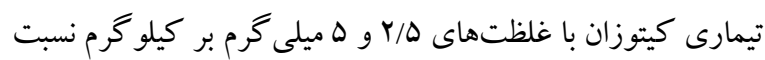

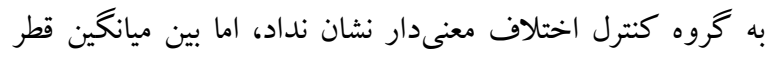

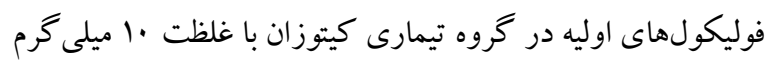

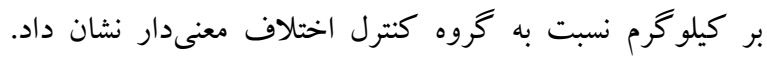

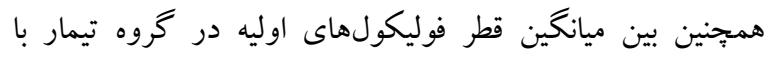

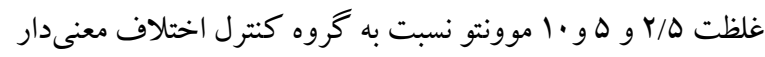

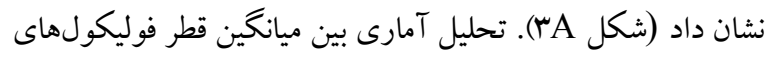

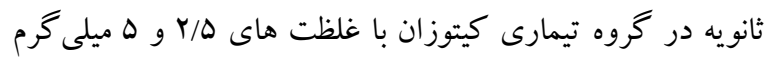

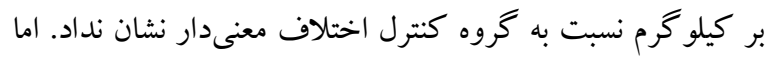

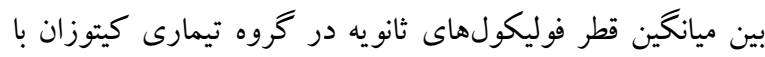

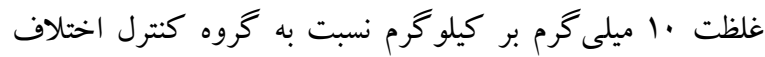

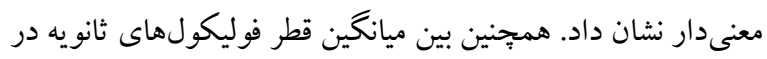




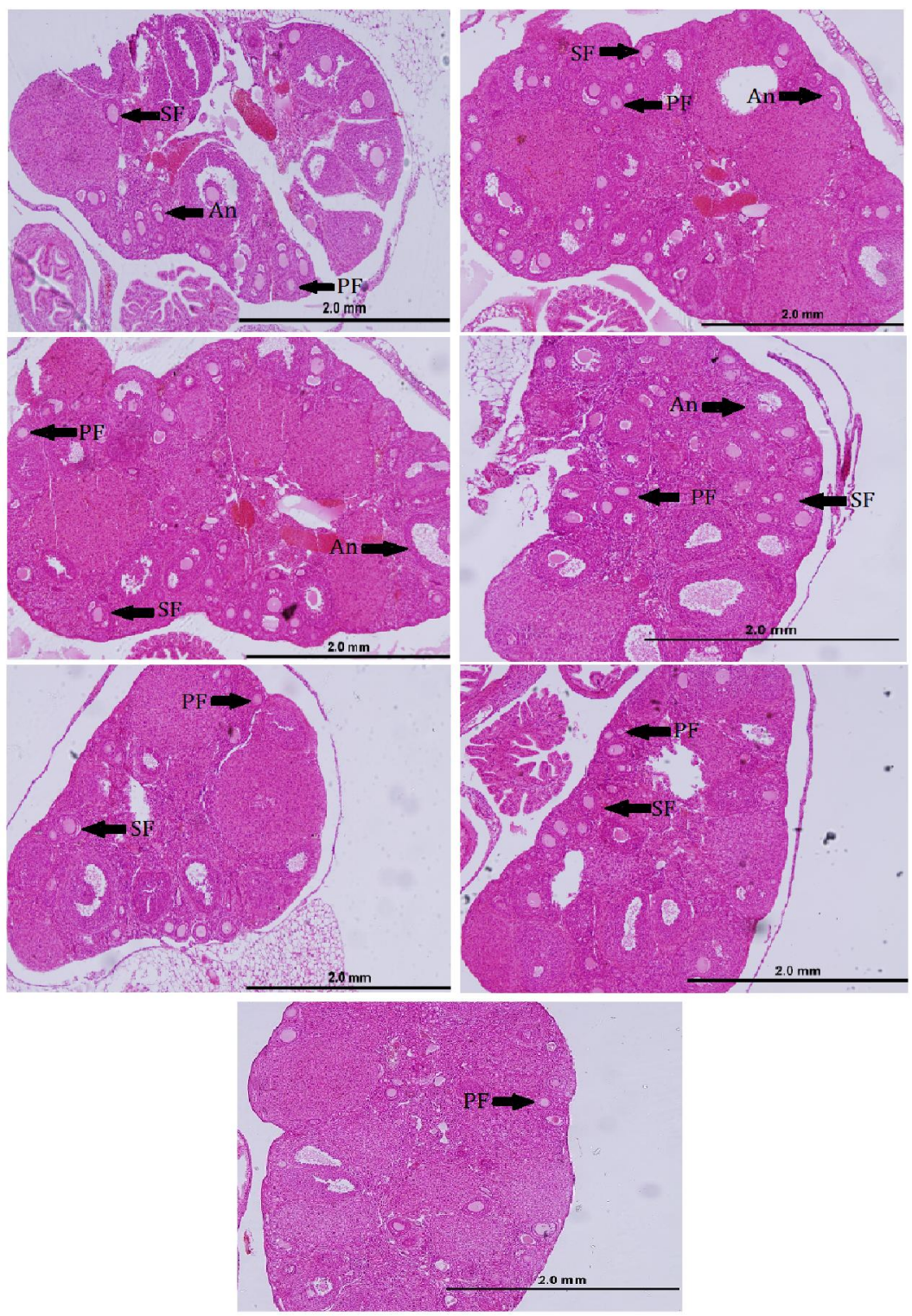

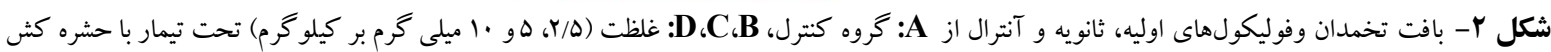

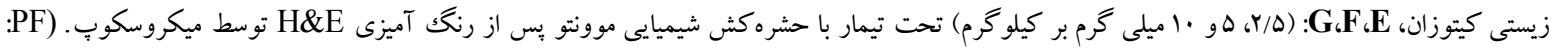

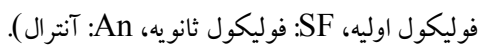

Fig. 2. Micrographs of ovaries, primary follicles, secondary follicles and antral follicles from A: control group, B, C, D: $2.5,5$ and $10 . \mathrm{mg} / \mathrm{kg}$ chitosan-treated groups after H\&E staining, respectively; E, F, G: $2.5,5$ and $10 \mathrm{mg} / \mathrm{kg}$ Movento-treated groups after H\&E staining, respectively. (PF: primary follicles, SF: secondary follicles, An: antral follicles).

$$
\begin{aligned}
& \text { •ا ميلى گرم كيتوزان با نسبت به گروه كنترل اختلاف معنىدار است. شايان ذكر است كه سطح هورمون هاى استراديول، LH و }
\end{aligned}
$$

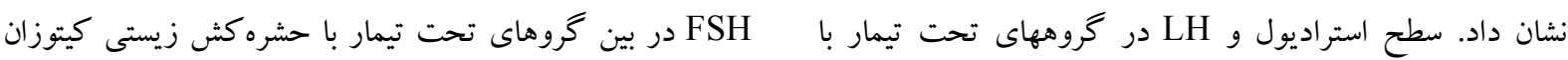

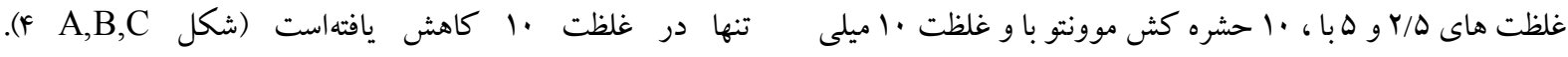

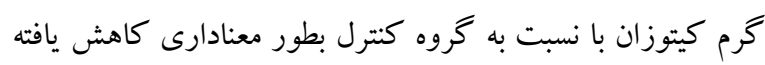




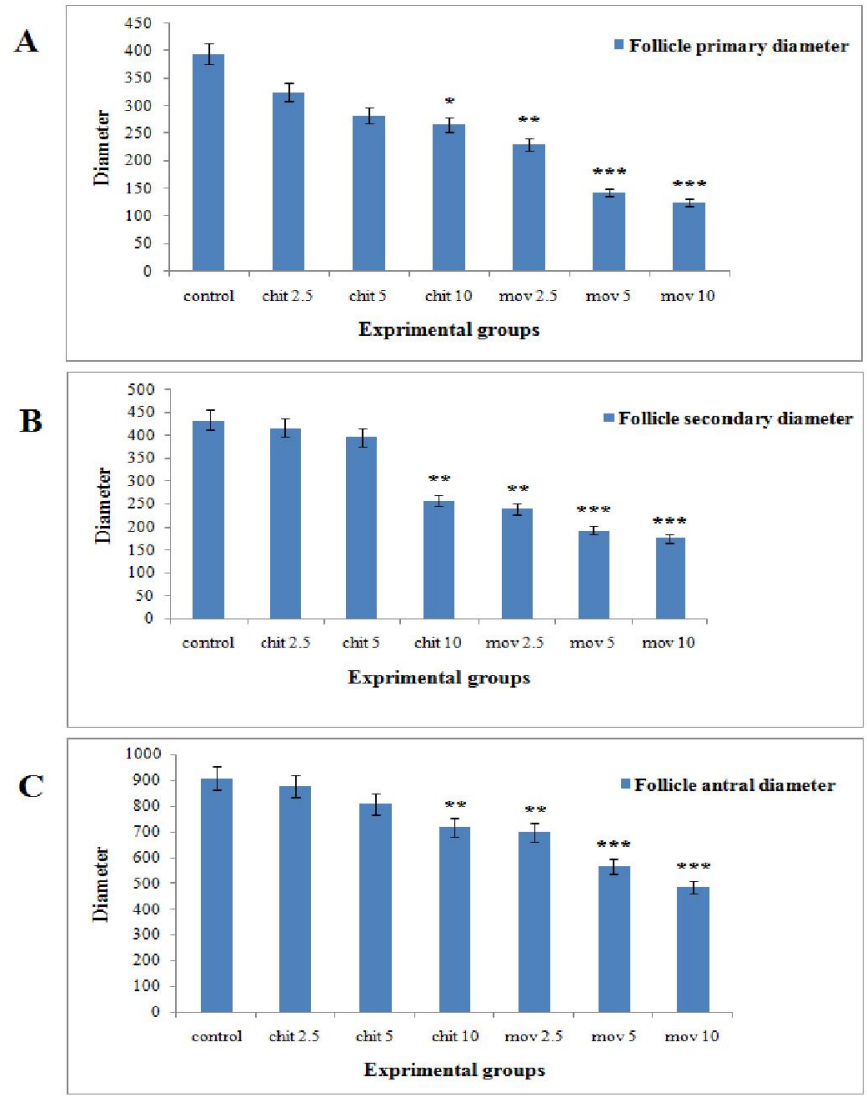

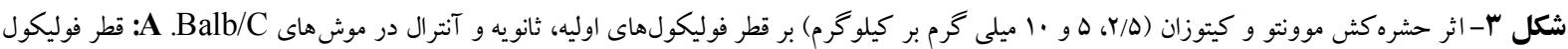

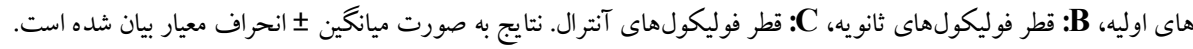

Fig. 3. The effect of Movento and chitosan exposure (2.5, 5 and $10 . \mathrm{mg} / \mathrm{kg}$ ) on the diameters of primary, secondary and antral follicles in Balb/C mice. A: Diameter of primary follicles, B: Diameter of secondary follicles, C: Diameter of antral follicles. The results are the means \pm SD.

و هورمونى شده است كه مشابه مطالعاتى كه Farr و همكاران

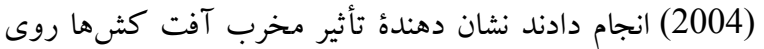
جرخه تخمدانى است. مطالعات نشان دادهاند كه آفت كشهاى شيميا يى باعث اختلال در عملكرد هورمونى زنان و اثرات منفى بر سلى بارورى مى شود و بويزه جرخ خهُ تخمدانى را مختل ميكند. در مطالعة Mokhtar (2013) مشخص شد كه حشره كشها باعث اختلال در تنظيمات هورمونى، تغيير در سطح هورمونهاى

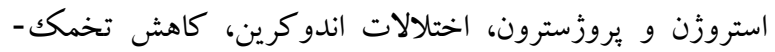
كذارى و بارورى، افزايش آترزى فوليكولى در موشها و همجنين منجر به تغييرات در بيان زنهاى تخمدان و فوليكولوزنز مى نتايج تحقيق حاضر نيز كاهش معنىدار در سطح هورمونهاى
نتايج حاصل از اين بزوهش نشان داد كه حشرهش موونتو موجب القاء اثرات توكسيك بر روى سيستم توليدمثلى ماده و باعث بر هم خوردن تعادل هورمونى و تغييرات تخمدانى مىشود. حشرهشها بهطور گسترده در سراسر دنيا به ويزه در كشاورزى، صنعت و يزشكى براى از بين بردن حشرات و آفات مورد استفاده

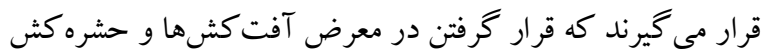
ها مى تواند باعث طيف گستردهاى از مشكلات بارورى در مردان، زنان و كودكان شود. اما اطلاعات كمى راجع به اثرات احتمالى آنها بر سلامتى بهويزه اثرات آنها بر سيستم توليدمثلى ماده در

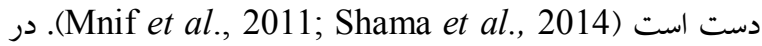
تحقيق حاضر حشره كث شيميايى موونتو باعث تغييرات تخمدانى 
$\mathbf{A}$

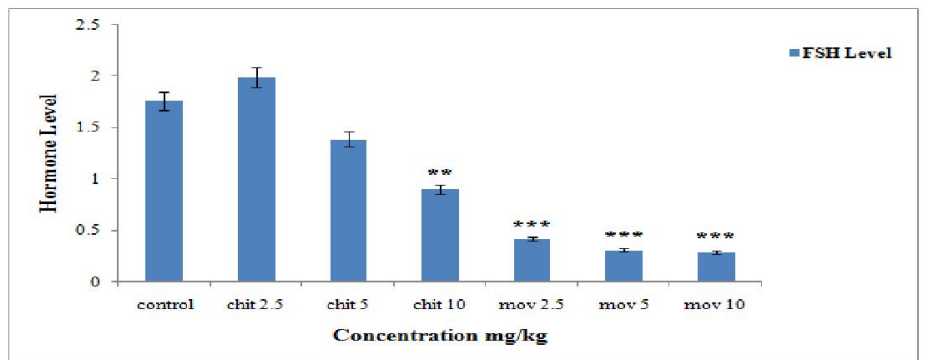

B

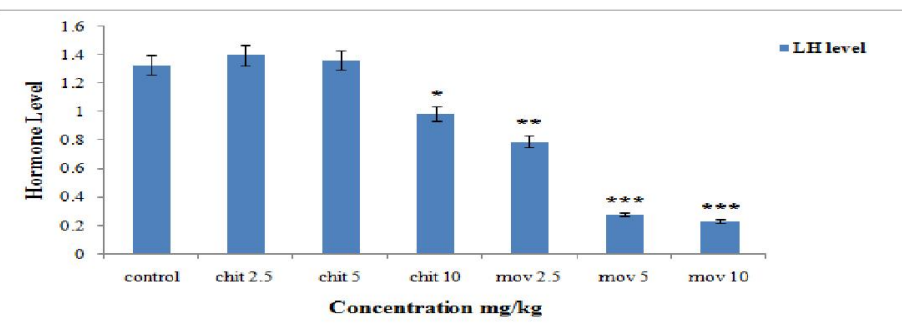

C

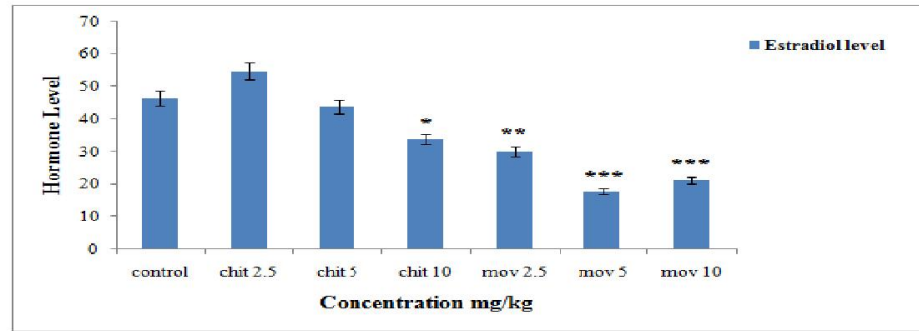

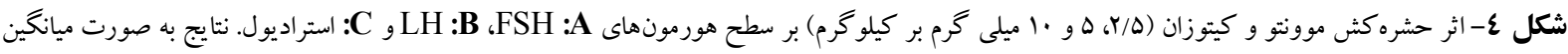
I انحراف معيار بيان شده است.

Fig. 4. Effect of movento $(2.5,5,10 \mathrm{mg} / \mathrm{kg})$ and chitosan $(2.5,5,10 \mathrm{mg} / \mathrm{kg})$ on A: FSH, B: $\mathrm{LH}$ and C: estradiol level. The results are the means \pm SD from three independent experiments.

نشان داده شد كه درمعرض قرار گرفتن موشهاى نر با حشره كش موونتو باعث تغييراتى در بيضه موش و همجنين افز ايش اسبرمهاى غيرطبيعى، هيبواسيرميا در ابيديدم، كاهش وزن بيضه و دزنراسيون بافت بيضه در موش نر مىشود. بهعلاوه مطالعات روى اين تركيب نشان داده است كه اين ماده باعث تغييرات در شاخصهاى بيوشيميايى خونى و سلولهاى كبدى در موشهاى صحرايى نر شده و موجب افزايش سطح ترى كليسيريد، كلسترول و آلبومين و و ايجاد تغييرات بافتى در كبد، كليه و لوزالمعده مىشود كه هم راستا با تحقيق حاضر نشان (Sverdrup et al., 2012)

$$
\text { دهندة القاء آسيب بر موجود زنده است. }
$$

نتايج بهدست آمده از تحقيق حاضر نشان داد كه تيمار موشهاه با موونتو باعث كاهش معنىدارى در تعداد و قطر فوليكولهاى
LH ، FSH نشان داد كه هم راستا با بزروهشهاى فوق نشان دهندة اعمال تغيير هورمونى حشره كشها است. همجنين Sharma و همكاران

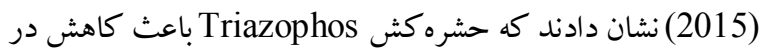
سطح هورمونهاى يروزسترون در موشها مى شود. حشره كش

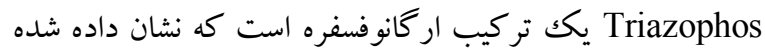
باعث القاى سميت در خون، كبد و كليه در موشهاى ماده مى شود، اما مطالعات روى موش هاى ماده القاى استرس اكسيداتيو در سيستم توليدمثلى ماده و القاء اثرات سمى روى تخمدان، تغييرات هورمونى و آيويتوزيس را نشان داده است. يافتهاى يثزوهش حاضر نشان داد حشرهش موونتو باعث كاهش در وزن تخمدان موشها شد. در مطالعهاى در سال r. r r 


\section{REFERENCES}

Bretveld, R.W., Thomas, C.M.G., Scheepers, P.T.J., Zielhuis, G.A. and Roeleveld, N. 2006. Pesticide exposure: the hormonal function of the female reproductive system disrupted? - Reprod. Bio. Endocrinol. Bio. Med. Cent-ral 4: 1-14.

Etchechury, F.M, Gramont, S., Sanchez, R., Romero, C., Enriquez, R., Cervantes, L., Olibarria, R., Millan, G. and Madri, A. 2015. Spirotetramat induces histological and biochemical changes in Wistar rats. - Rev. Toxicol. 30: 215-217.

Farr, S.L., Cooper, G.S., Cai, J., Savitz, D.A. and Sandler, D.P. 2004. Pesticide useand menstrual cycle characteristics among premenopausal women in the agricultural health study. - Am. J. Epidemiol. 160: 1194-1204.

Fisher, R. and Weiss, H.C. 2008. Spirotetramat (Movento): discovery, synthesis and physico-chemical properties. Bayer CropScience J. 61: 127-140.

Gupta, R.K., Miller, K.P., Babus, J.K. and Flaws, J.A. 2006. Methoxychlor inhibits growth and induces atresia of antral Follicles through an oxidative stress pathway. Toxicol. Sci. J. 93: 382-389.

Meeker, J.D., Ryan, L., Barr, D.B. and Hauser, R. 2006. Exposure to non-persistent insecticides and male reproductive hormones. - Epidemiol. J. Pubmed 17: 61-68.

Mnif, W., Hassine, A., Bouaziz, A., Bartegi, A. and Thomas, O. 2011. Effect of endocrine disruptor pestisides. A Review. - Int. J. Environ. Res. Public Health (IJERPH) 8: 2265-2303.

Mokhtar, H.I., Abdel, H.A., Elmazoudy, R.H., Abdelwahab, W.M. and Saad, M.I. 2013. Effect of methomyl on fertility, embryotoxicity and physiological parameters in female rats. - J. App. Pharm. Sci. (JAPS) 3: 109-119.

Nauen, R., Reckmann, U., Thomzik, J. and Thielert, W. 2008. Biological profile of spirotetramat (movento) a new two way systemic (ambimobile) insecticide against sucking species. - Bayer CropScience J. 61: 245-277.

Ngoula, F., Watcho, P., Bouseko, T.S., Kenfack, A., Tchoumboué, J. and Kamtchouing, P. 2007. Effects of propoxur on the reproductive system of male rats. - Afr. J. Rep. Health (AJRH) 11: 125-132.

Ngoula, F., Ngouateu, O.B, Kana, J.R, Defang, H.F, Watcho, P., Kamtchouing, P. and Tchoumboué, J. 2012. Reproductive and Developmental Toxicity of Insecticides. Afr. J. Rep Health (AJRH) 10:429-457.

Saleh, A.M.T., Hijji, A.M., Elel, S.J. and Al Yacoub, A.N. 2014. Effect of carbamate insecticide, Lannate, on the gonads of mice. - J. Adv. Lab Res. Biol. (JALRB) 5: 140-145.

Shama, D., Sangha, G.K. and Khera, K.S. 2014. Triazophos induced oxidative stress in female albino rats. - Int. J. Adv. Res. (IJAR) 2:746-754.

Sangha, G.K, Kaur, K. and Khera, K.S. 2013. Cypremethrine-induced pathological and biochemical changes in reproductive organs of female rats. - J. Environ. Biol. 34: 99-105.

Sharma, D., Sangha, G.K. and Khera, K.S. 2015. Triazophos-induced oxidative stress and histomorphological changes in ovary of female Wistar rats. - J. Pestic. Biochem. Physiol. 117: 9-18.

$$
\begin{aligned}
& \text { تخمدانى (اوليه و ثانويه و آنترال) مىشود كه مشابه با تحقيقات } \\
& \text { صورت گرفته توسط Saleh (2014) بيان گر كاهش فوليكولهاى } \\
& \text { تخمدانى و كاهش جسم زرد و افزايش فوليكولهاى آترزى در } \\
& \text { موش هاى تحت تيمار با حشره كش كاربامات است. } \\
& \text { مطالعات صورت گرفته نشان مىدهد كه قرار گرفتن در معرض } \\
& \text { حشرهكشها روى سيستم توليدمثلى ازطريق اختلال در عملكرد }
\end{aligned}
$$

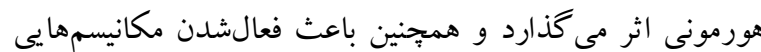

$$
\begin{aligned}
& \text { مىشوند كه آسيب مستقيم روى ساختار سلول دارد و موجب } \\
& \text { تداخل فرايندهاى بيوشيميايى مىشود كه براى عمل كرد نرمال }
\end{aligned}
$$

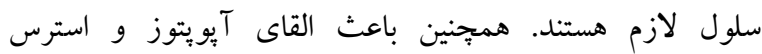

$$
\begin{aligned}
& \text { اكسيداتيو از طريق افزايش راديكالهاى آزاد و كاهش آنتى - } \\
& \text { اكسيدانها مىشوند كه مىتوانند از مكانيسمهاى احتمالى متأثر از }
\end{aligned}
$$

در معرض قراركيرى حشره كثها باشند ( Bretveld et al., .(2006; Gupta et al., 2006

تحقيق حاضر نشان مىدهد كه حشره كش زيستى كيتوزان در

غلظتهاى يايين تر از · إميلى گرم هيج اثر تخريبى بر روى

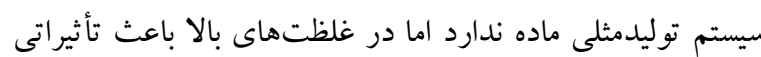
روى بافت تخمدان و القاء سميت روى سيستم توليدمثلى ماده مى شود. مطالعات Yanti (2009) نيز مؤيد ايمنبودن اين تركيب در غلظتهاى بايين بوده و نشان مىدهد كه فعاليت كيتوزان يكك تحريك كننده طبيعى دفاعى در سيستم دفاعى گياهان هستند، به همين دليل كيتوزان نقش بالقوهاى بعنوان حشرهكش زيستى جايخزين براى كياهان دارد. نتيجه تيرى نتايج اين يزوهش نشان داد كه موونتو همانند ساير حشرهكشهاى شيميايى موجب تغيير سطح هورمونهاى جنسى و ايجاد تغيير در ساختار فوليكولهاى تخمدانى، تخمدان و القاء آسيب به سيستم توليدمثلى ماده شده، اين در حالى است كه كيتوزان به دليل اعمال حداقل آسيب به ساختار توليدمثلى ماده مى تواند به عنوان حشره كث زيستى مورد استفاده باشد.

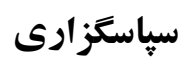

از همكاران مركز تحقيقاتى بيولوزى كاربردى و تكوين جانورى دانشگاه آزاد اسلامى واحد مشهد كه در اجراى اين يثزوهش همكارى داشتند سياسگزاريم. 
Sverdrup, L.E., Bjorge, C., Eklo, O.M., Grung, M., Kallqvist, T., Klingen, I., Lag, M. and Ropstad, E. 2012. Risk assessment of the insecticide Movento 100 SC with the active substance spirotetramat. - Bayer CropScience J. 13: 1-25.

Yanti, S.D, Nugroho, P.T, Aprisa, R. and Mulyana, E. 2009. The potential of chitosan as alternative biopesticide for postharvest Plants. - As. J. Food Ag-I nd 19: 241-248.

Yehia, M.A, El-Banna, S.G. and Okab, A.B. 2007. Diazinon toxicity affects histophysiological and biochemical parameters in rabbits. - Exp. Toxicol. Pathol. 59: 215-25.

\section{$* * * * *$}

Kaboli Kafshgiri, S., Parivar, K., Baharara, J., Hayati Roodbari, N. and Kerachian, M.A. 2017. Comparison the effect of movento as chemical pesticide with chitosan as biologic pesticide on female reproductive system in Balb/C mice. - Nova Biol. Rep. 3: 279-287.

كابلى كفشعيرى، س.، بريور، ك.، بهارارا، ج.، حياتى رودبارى، ن. و

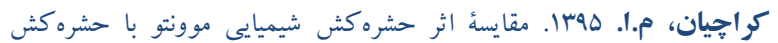

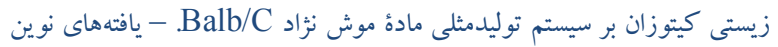
در علوم زيستى r: rVA-YAV. 